УДК 374:352.07(477.53)

DOI: 10.37026/2520-6427-2020-103-3-163-166
Лариса ВОРОНА,

кандидат педагогічних наук, докторант кафедри педагогіки Луганського наиіонального університету імені Тараса Шевченка

\title{
ВПЛИВ ОРГАНІВ МІСЦЕВОГО САМОВРЯДУВАННЯ ПОЛТАВЩИНИ НА РОЗВИТОК ПОЗАШКІЛЬНОЇ ОСВІТИ В ОБЛАСТІ: ПРОЕКТНО-ПРОГРАМНИЙ ПІДХІД
}

\begin{abstract}
У статті обтрунтовано використання органами державної влади та місиевого самоврядування проєктно-програмного підходу з метою розвитку системи позашкільної освіти та реалізації державноі освітньої політики на теренах Полтавщини. Проведено аналіз освітніх програм регіону, зокрема детально досліджено програму “Опікуємося освітою» на предмет сприяння розвитку системи позашкілля та ефективності вирішення основних освітніх завдань у ракурсі Нової украӥнської школи.

Ключові слова: система позашкілля, позашкільна освіта, заклади позашкільної освіти, проєктно-програмний підхід, виховання, місиеве самоврядування, державна політика.
\end{abstract}

В статье обосновано использование органами государственной власти и местного самоуправления проектно-программного подхода с иелью развития системь внешкольного образования и реализации государственной образовательной политики на Полтавщчине. Проведен анализ образовательных программ региона, в частности подробно исследована программа «Заботимся об образовании» на предмет содействия развитию системы внешкольного образования и эффективности решения основных образовательных задач в ракурсе Новой украинской школьл.

Ключевые слова: система внешкольного образования, внешкольное образование, учреждения внешкольного образования, проектно-программный подход, начионально-патриотическое воспитание, местное самоуправление, государственная политика.

In the article the author examines using be public authorities and local governments of the project-program approach to the development of extra-curricular system in Poltava region for the implementation of state educational policy. Local governments, as the founders of after-school education institutions, should promote the availability and quality of after-school education in the regions. Lack of experience and knowledge of effective management, lack of long-term vision and opportunities for extra-curricular education, narrow perception of extracurricular activities as a type of leisure, not as a means of comprehensive development of the individual and acquisition of vital competencies, a way to invest in development of human capital, lead to elimination or reorganization of after-school education institutions by local authorities. In recent years, 19 extra-curricular educational institutions in Ukraine have been closed by the decision of local self-government bodies. Negative leadership belongs to Kherson, Vinnytsia, Zaporizhia, Ternopil and Poltava regions. Therefore, the author emphasizes the importance of supporting local government and public authorities in the activities and development of extra-curricular education, in the context of reforming the educational sector of Ukraine it is important to find effective ways to develop after-school education development and creative self-realization of children, promotes their social security and professional orientation, prevention of negative manifestations in the youth environment.

The analysis of educational programs of the region is carried out and the program "We take care of education» is investigated in detail for the purpose of assistance of development of system of extracurricular and efficiency of the decision of the basic educational tasks in the foreshortening of the New Ukrainian school.

Key words: out-of-school system, out-of-school education, out-of-school education institutions, project-program approach, national-patriotic education, local self-government, state policy.

Постановка проблеми. Позашкільна освіта, або позашкілля, в системі безперервної освіти в Україні в умовах сьогодення набуває особливої ваги і впливу на формування компетентностей дітей та молоді, чинить домінуючий вплив на систему національно-патріотичного виховання, що надзвичайно важливо у світлі подій, що відбуваються на Сході України. Вона спрямована на розвиток здібностей та обдарувань вихованців, учнів і слухачів, задоволення їхніх інтересів, духовних запитів і потреб у професійному визначенні. Загалом позашкільна освіта - це сукупність знань, умінь та навичок, які вихованці, учні та слухачі отримують у закладах позашкільної освіти (далі - ЗПО) у час, вільний від навчання в закладах загальної середньої освіти та ін.

Сьогодні в рамках Концепції Нової української школи [4] варто говорити про вдосконалення та трансформацію позашкільної освіти, адже на неї покладено 
важливу місію - виховання учнівської молоді. Виховний процес, як наголошується в Концепції, має стати невід'ємною складовою освітнього процесу в цілому, пронизуючи навчальну діяльність, систему позакласної та позашкільної роботи. В умовах реформування Нової української школи основним завданням виховання $є$ створення таких умов, за яких розвиватиметься людина європейського мислення. Саме національно-патріотичне виховання дітей і молоді визначено пріоритетним напрямом в організації виховної роботи закладів освіти. При цьому позашкільна освіта повинна стати основою для виховання особистості, адже має для цього найбільш сприятливе середовище - добровільність навчання та вільний вибір на́пряму діяльності.

У системі позашкілля ключова роль відведена виховній роботі як організованому процесу, що спрямований на формування всебічно і гармонійно розвиненої особистості. Основні принципи організації виховного процесу визначаються у Концепції національного виховання, Національній програмі виховання дітей та молоді, серед яких основними є: акмеологічний принцип, національна цілеспрямованість, культуровідповідність, цілісність, психологічний супровід, технологізація, діалог та ін. [4].

Державна політика у сфері позашкільної освіти здійснюється на принципах: доступності позашкільної освіти громадянам незалежно від раси, кольору шкіри, політичних, релігійних та інших переконань, статі, етнічного та соціального походження, майнового стану, місця проживання, мовних або інших ознак; фінансування державних та комунальних закладів позашкільної освіти відповідно до їх структури; добровільності вибору типів закладів позашкільної освіти, форм позашкільного навчання і видів діяльності; науковості; світського характеру освіти у державних і комунальних закладах позашкільної освіти; правового і соціального захисту вихованців, учнів і слухачів в їх прагненні до вільного, різнобічного розвитку особистості; інших принципах, визначених Законом України «Про освіту» [9].

На думку науковців та практиків, концепція цілепокладання, яка лежить в основі проєктно-програмного підходу, якраз і спрямована на розв'язання актуальних проблем освітньої галузі, виражає спільне прагнення всіх складових громадянського суспільства, передбачає досягнення прогнозованих результатів, а також $\epsilon$ важливим інструментом впливу органів державної влади та місцевого самоврядування на розвиток системи освіти як у регіоні зокрема, так і в державі в цілому. Про це свідчить і досвід використання проєктно-програмного підходу органами місцевого самоврядування Полтавщини, спрямованого на розвиток освітньої галузі регіону.

Аналіз наукових досліджень і публікацій. Питання діяльності органів місцевого самоврядування у сфері освіти, зокрема функціонування закладів освіти, розглядалися низкою науковців та представляють різні напрями дослідження - юридичний, економічний, педагогічний, публічне управління тощо. Дану проблематику окреслено в наукових працях Л. Гриневич, Б. Данилишина, М. Кропивки, П. Ворони та ін.

Серед дослідників позашкільної освіти варто виокремити таких учених та практиків, як С. Боровська, О. Биковська, Я. Биковський, Т. Биковський, Л. Дейдиш, С. Каричковська, В. Каричковський, О. Ковальчук, Н. Кардаш, С. Лихота, О. Кузик, В. Найдюк,
В. Кодря, Л. Оружа, Л. Олексюк-Казо, Т. Паливода, I. Первушевська, О. Рудика, Н. Савенко, Г. Суркова, Л. Ткаченко, О. Шевченко, Н. Цвікова, А. Ясинська та ін. [5].

Разом із тим, учені наголошують на важливій ролі держави та органів місцевого самоврядування у визначенні та реалізації стратегії розвитку позашкільної освіти в кожному регіоні України, зокрема звертають увагу на модернізацію методології та практики позашкілля. При цьому особлива роль відводиться проєктно-програмному підходу як способу структуризації, що застосовується 3 метою вирішення завдань комплексного планування й управління освітнім процесом, забезпечує пріоритет першочергових цілей і завдань, досягнення максимально значущих кінцевих результатів. Даний підхід також передбачає об'єднання цілей, строків, управління в складі цілісного процесу, спрямованого на розвиток освіти в регіоні, досягнення стратегічних завдань за допомогою відповідних цільових програм розвитку.

Сутність нашого дослідження полягає в узагальненні та виокремленні регіональної специфіки використання проєктно-програмного підходу 3 метою розвитку освітнього сектору регіону, що важливо для стимулювання діяльності системи закладів позашкільної освіти регіону [3].

Мета статті - здійснити аналіз регіональних освітніх програм, прийнятих Полтавською обласною радою; грунтовно дослідити програму «Опікуємося освітою» 3 метою сприяння розвитку системи позашкілля та ефективності вирішення основних освітніх завдань у ракурсі Нової української школи.

Виклад основного матеріалу. Розвиток освіти, зокрема й позашкільної, пошук нових форм і методів заохочення дітей до навчання та виховання повинні бути пріоритетними напрямами діяльності органів влади. У зв'язку з цим для розвитку позашкільної освіти в кожному регіоні України органами місцевого самоврядування, особливо на рівні обласних рад, використовується проєктно-програмний підхід, що спрямований на вирішення проблем, які виникають у сфері освіти, як-от: створення належних умов для здобуття вихованцями, учнями та слухачами позашкільної освіти; збереження та розвиток мережі державних та комунальних позашкільних закладів освіти без права їх перепрофілювання, перепідпорядкування, злиття, закриття тощо; координація зусиль органів виконавчої влади, органів місцевого самоврядування, підприємств, установ, організацій, об'єднань громадян із метою розвитку позашкільної освіти тощо [2].

Вагомий досвід використання проєктно-програмного підходу в управлінні освітнім процесом має Полтавщина. На сьогодні в області діє кілька освітніх програм, серед яких:

- Обласна програма «Опікуємося освітою» на 2017-2020 роки;

- Програма реалізації концепції допризовної підготовки і військово-патріотичного виховання молоді Полтавської області на 2015-2020 роки;

- Обласна цільова програма національно-патріотичного виховання дітей та молоді на 2017-2020 роки;

- Програма національно-патріотичного виховання дітей та молоді у Полтавській області на 20162020 роки; 
- Обласна програма «Оздоровлення та відпочинку дітей» на 2020-2024 роки.

Усі зазначені вище програми були прийняті за сприяння депутатського корпусу Полтавської обласної ради (активний процес обговорення у профільній комісії) та з урахуванням громадської думки, передусім освітян, а також внутрішньо-регіональних освітніх особливостей Полтавщини.

Пропонуємо більш грунтовно розглянути Обласну програму «Опікуємося освітою».

Полтавська обласна рада на пленарному засіданні дванадцятої сесії сьомого скликання рішенням від 23 грудня 2016 року № 2316, керуючись частиною 2 статті 43 Закону України «Про місцеве самоврядування в Україні», статтею 22 Закону України «Про місцеві державні адміністрації», статтею 14 Закону України «Про освіту» та розглянувши розроблений обласною державною адміністрацією проєкт, прийняла Обласну програму «Опікуємося освітою» на 2017-2020 роки (далі - Програма). У ході прийняття даної Програми були враховані висновки постійних комісій обласної ради, пропозиції та думки педагогічної громадськості області, громадських організацій. У ході обговорення основна увага акцентувалася на тому, що дана Програма покликана поліпшити стимулювання розвитку творчого потенціалу вчителів області, підвищувати їхню професійну майстерність, сприятиме заохоченню й підтримці обдарованих і талановитих дітей та молоді, вирішуватиме проблеми з фінансуванням закупівлі науково-методичної літератури, фахових періодичних методичних видань для закладів освіти, зміцнення їх матеріально-технічної бази. Загалом Програма стала базовим нормативним документом для розвитку позашкілля у Полтавській області [7].

Метою програми «Опікуємося освітою» було визначено:

- забезпечення конституційного права громадян на здобуття якісної освіти, рівний доступ до неї, приведення системи освітньої роботи у відповідність до потреб дитини;

- формування інтелектуального потенціалу регіону шляхом створення в області сприятливих умов для пошуку, підтримки інтелектуально і творчо обдарованих дітей та молоді, самореалізації творчої особистості в сучасному суспільстві;

- забезпечення ефективності виявлення та підтримки творчої праці вчителів, підвищення їхньої професійної майстерності, популяризації педагогічних здобутків;

- створення умов для ефективного науково-методичного забезпечення регіонального компонента освіти в Полтавській області у 2017-2020 рр.;

- удосконалення планування та супроводу фінансово-господарської діяльності, матеріально-технічного та методичного забезпечення контролю дотримання безпечних умов організації освітнього процесу в закладах і установах освіти, що перебувають у спільній власності територіальних громад сіл, селищ, міст області, а також закладах і установах освітньої галузі в цілому;

- модернізація матеріально-технічної бази окремих закладів освіти із метою належної експлуатації будівель;

- забезпечення готовності закладів освіти до нового навчального року та недопущення випадків призупинення освітнього процесу через виникнення нештатних ситуацій;
- зменшення витрат бюджетних коштів на оплату послуг з опалення, економне споживання енергоресурсів;

- економія коштів на проведення позапланових поточних ремонтів;

- забезпечення санітарно-гігієнічних умов для навчання та виховання дітей та підлітків відповідно до вимог нормативних документів;

- зменшення рівня захворюваності та поліпшення здоров'я учасників освітнього процесу, а також створення комфортних умов для їх перебування у закладах;

- узгодження дій місцевих органів виконавчої влади та органів місцевого самоврядування усіх рівнів щодо цілеспрямованої підготовки молоді до захисту Вітчизни, виховання на патріотичних, історичних та бойових традиціях українського народу, що особливо важливо у час російської агресії на Сході України [6].

Варто зазначити, що всі положення Програми неабияк стосуються розвитку системи позашкілля області, особливо в частині підтримки обдарованих дітей та педагогів, які працюють 3 ними, різноманітних заходів та тренінгів, що стимулюють освітній процес та національно-патріотичне виховання тощо.

Актуальність програми «Опікуємося освітою» на даному етапі підсилюється дією Концепції «Нова українська школа», яка пояснює ідеологію реформування системи освіти, обгрунтовує необхідність підготовки випускника нової школи як цілісної особистості, усебічно розвиненої, здатної до критичного мислення, патріота з активною позицією, новатора, здатного змінювати навколишній світ, розвивати економіку, конкурувати на ринку праці, вчитися впродовж життя.

Програма також дає змогу стимулювати розвиток творчого потенціалу педагога, підвищувати його професійну майстерність, сприяє заохоченню й підтримці обдарованих і талановитих дітей і молоді (передусім через систему закладів позашкілля), їхній підготовці до всеукраїнських учнівських олімпіад із навчальних предметів.

Програма включає чотири важливі напрями, в реалізації яких активно задіяні заклади позашкільної освіти Полтавської області:

1. Підтримка роботи з обдарованими і талановитими дітьми та молоддю.

2. Розвиток післядипломної освіти (методична та курсова робота закладів позашкілля і для працівників закладів).

3. Удосконалення планування та супроводу фінансово-господарської діяльності, матеріально-технічного та методичного забезпечення, контролю дотримання безпечних умов організації освітнього процесу в закладах і установах освіти, що перебувають у спільній власності територіальних громад сіл, селищ, міст області, а також закладах і установах освітньої галузі в цілому.

4. Національно-патріотичне та військово-фізичне виховання.

Зважаючи на те, що Концепцією «Нова українська школа» передбачено вдосконалення роботи 3 виявлення та розвитку нахилів обдарованих дітей i молоді, варто виокремити такі пункти програми: виявлення обдарованих і талановитих дітей і молоді, створення умов для їх розвитку; підготовка учасників I, II та III етапів Всеукраїнського конкурсу-захисту науково-дослідницьких робіт учнів-членів Малої академії наук України [6]. Із цією метою в Програмі 
передбачено оплату педагогів, які забезпечуватимуть освітній процес, організацію харчування, проживання та підвезення учасників, оплату відряджень під час проведення навчально-тренувальних зборів учасників I, II та III етапів Всеукраїнського конкурсу-захисту науково-дослідницьких робіт учнів-членів Малої академії наук України. Крім того, Програма забезпечує адресну підтримку обдарованих і талановитих дітей та молоді шляхом виплати грошових винагород переможцям III етапу Всеукраїнських учнівських олімпіад із навчальних предметів, переможцям II етапу конкурсузахисту науково-дослідницьких робіт учнів-членів Малої академії наук. Забезпечується матеріальне заохочення педагогічних та науково-педагогічних працівників, які підготували переможців III етапу Всеукраїнських учнівських олімпіад із навчальних предметів та II етапу конкурсу науково-дослідницьких робіт учнів-членів Малої академії наук України [6].

Програма «Опікуємося освітою» також спрямована на вирішення проблем, які неможливо розв'язати у процесі поточної роботи та які наявні у системі освіти Полтавщини та $є$ важливою сферою соціально-економічного, духовного і культурного розвитку сіл і міст області. Залучення коштів обласного бюджету у перспективі дає можливість забезпечувати якісну підготовку окремих закладів освіти до нового навчального року, опалювального сезону та попередить виникнення аварійних ситуацій у ході освітнього процесу, впровадити енергозберігаючі та енергоефективні технології тощо. Саме для вирішення цих та інших нагальних питань і виникла необхідність прийняття програми «Опікуємося освітою» [6].

Закон України «Про місцеве самоврядування в Україні» [8] покладає відповідальність за складання програм соціально-економічного розвитку та цільових програм на виконавчі комітети рад та державні адміністрації. При цьому підготовча робота повинна здійснюватися під керівництвом голови. Відповідно до означеного вище Закону місцеві програми повинні складатися щорічно з урахуванням Державної програми економічного і соціального розвитку на відповідний рік. У статті 11 даного Закону пропонується така структура програми:

- аналіз соціально-економічного розвитку відповідної територіально-адміністративної одиниці за попередній і поточний роки та характеристика головних проблем розвитку ії економіки та соціальної сфери, зокрема й освіти;

- стан використання природного, виробничого i трудового потенціалу, екологічна ситуація у відповідній територіально-адміністративній одиниці;

- можливі шляхи розв'язання проблем розвитку економіки і соціальної сфери відповідної територіально-адміністративної одиниці;

- мета та пріоритети соціально-економічного розвитку відповідної територіально-адміністративної одиниці в наступному році;

- система заходів місцевих органів виконавчої влади щодо реалізації соціально-економічної політики з визначенням термінів виконання та виконавців;

- основні показники соціально-економічного розвитку відповідної адміністративно-територіальної одиниці;

- дані про отримання та використання доходів від розпорядження об'єктами комунальної власності, показники розвитку підприємств та організацій, що $є$ об'єктами комунальної власності [8]
Як бачимо, у наведеній структурі програми представлені три елементи: економіка, екологія та соціум. Доведено, що сталий соціальний розвиток забезпечується сукупністю «...економічних, соціальних, політичних, духовних процесів, які розгортаються в суспільстві з метою забезпечення гармонійного розвитку людини, суспільства, економіки та довкілля».

Висновки. Таким чином, зауважимо, що система позашкільної освіти Полтавської області як важлива складова освітнього процесу України загалом відіграє одну з домінуючих ролей у політичному, духовному та соціальному розвитку суспільства та $є$ формуючою складовою процесу гармонійного розвитку дитини. У зв'язку з цим прийняття освітніх програм, серед яких і програма «Опікуємося освітою», на рівні області, району, громади ще більше стимулюватиме процес гармонізації людини та реалізації ії здібностей. При цьому системі позашкілля відводиться одна 3 провідних ролей, що зазначено і в Концепції Нової української школи

Перспективи подальших розвідок у даному напрямі плануємо спрямувати на дослідження регіональних особливостей освітянських програм та інструментів їх моніторингу.

\section{СПИСОК ВИКОРИСТАНОЇ ЛІТЕРАТУРИ}

1. Биковська О., Громовий В. Позашкільна освіта: концептуальні засади в умовах реформування системи освіти України. Освітня політика: портал громадських експертів. URL: http://educationua.org/ ua/articles/435-pozashkilna-osvita-kontseptualni-zasadi (дата звернення: 10.06.2020).

2. Ворона Л. І. Особливості позашкільної освіти як складової освітнього простору Полтавщини. Педагогічні науки: історія розвитку, сучасний стан та перспективи досліджень : матеріали II науково-практичної конференції (м. Полтава, 27-28 берез. 2020 р.). Херсон : Молодий вчений, 2020. С. 6-9.

3. Карамишев Д. В., Бульба В. Г., Поступна О. В., Ростовська В. І. Розвиток системи позашкільної освіти на регіональному рівні як необхідний елемент у вихованні особистості. URL: http://www.kbuapa. kharkov.ua/e-book/db/2013-1/doc/6/05.pdf (дата звернення: 10.08.2020).

4. Концепція «Нова українська школа» від 14 груд. 2016 p. № 988-p. URL: https://mon.gov.ua/ua/tag/novaukrainska-shkola (дата звернення: 10.06.2020).

5. Стратегія розвитку позашкільної освіти. Oсві$m a$ : всеукраїнський громадсько-політичний тижневик (спецвипуск). 2018. № 35/36 (5833/5834). 19-26 вересня.

6. Програма «Опікуємося освітою на 2017-2020 роки». URL: https://C:/Users/user/AppData/Local/Temp/ Rar\$DIa7932.44365/Osnovna.pdf (дата звернення: 08.06.2020).

7. Харченко О. В. Нова українська школа: завдання і перспективи. Постметодика. 2016. № 2. С. 2-17.

8. Про місцеве самоврядування в Україні : Закон України від 21 трав. 1997 р. № 280/97-BP. URL: https://zakon.rada.gov.ua/laws/show/280/97-\%D0\% B2\%D1\%80 (дата звернення: 23.06.2020).

9. Про освіту : Закон України від 05 верес. 2017 р. № 2145-VIII. URL: https://zakon.rada.gov.ua/laws/show/ 2145-19 (дата звернення: 20.06.2020).

Дата надходження до редакиіï: 24.07.2020 p. 